\title{
The role of macrophytes in habitat structuring in aquatic ecosystems: methods of measurement, causes and consequences on animal assemblages' composition and biodiversity
}

\author{
O papel das macrófitas na estruturação de habitat em ambientes aquáticos: \\ métodos de medida, causas e consequências para a composição das \\ assembléias animais e biodiversidade
}

Sidinei Magela Thomaz and Eduardo Ribeiro da Cunha
Programa de Pós-graduação em Ecologia de Ambientes Aquáticos Continentais - PEA, Universidade Estadual de Maringá - UEM, CEP 87020-900, Maringá, PR, Brazil e-mail:smthomaz@nupelia.uem.br, edurcunha@gmail.com

\begin{abstract}
Aquatic macrophytes play an important role in structuring communities in aquatic environments. These plants provide physical structure, increase habitat complexity and heterogeneity and affect various organisms like invertebrates, fishes and waterbirds. The complexity provided by macrophytes has been exhaustively studied in aquatic environments. However, macrophyte complexity has rarely been measured in a standardized fashion, making comparisons among different studies and the establishment of general conclusions difficult. To address this issue, this review is focused on questions related to the habitat structural complexity provided by these plants, exploring: i) how complexity has been viewed by ecologists, with an emphasis on macrophyte studies; ii) the pros and cons of several methods used to quantify plant complexity; iii) the consequences of habitat structuring by macrophytes on invertebrates and fish and possible causes, mediated by habitat complexity, that lead to changes in these animal assemblages; iv) potential impacts of non-native macrophyte species on habitat complexity and v) the importance of complexity provided by macrophytes to management strategies for maintaining aquatic biodiversity. We examined literature produced in both temperate and tropical regions, but prioritized the latter. We found a great variety of habitat complexity measurements that are applied to aquatic macrophytes to understand their influence on attached animal assemblages. A lack of standardization (considering the wide range of techniques and scales of resolution used) limits comparisons between different studies exploring this subject, in which biological samples and physical substrates were used to explore these relationships. Macrophytes affect animal assemblages and promote biodiversity through a chain of mechanisms, related to habitat complexity, that involve the availability of shelter and feeding sites. Invasive macrophyte species may modify habitat structure and thus influence associated organisms. In this sense, they are suitable as the main focus of management strategies aimed at biodiversity restoration and conservation.
\end{abstract}

Keywords: aquatic vegetation, invasive species, diversity, habitat heterogeneity.

Resumo: Macrófitas aquáticas têm um importante papel na estruturação de comunidades em ambientes aquáticos. Essas plantas proporcionam estrutura física, aumentam a complexidade e a heterogeneidade de habitats e afetam vários grupos de organismos como invertebrados, peixes e aves aquáticas. A complexidade proporcionada pelas macrófitas tem sido exaustivamente estudada, porém, a mesma raramente tem sido medida de forma padronizada, dificultando comparaçóes entre estudos e o estabelecimento de conclusóes gerais. Com o objetivo de endereçar esse assunto, a presente revisão enfoca questóes relacionadas à complexidade estrutural de habitats proporcionada por essas plantas e explora: i) como a complexidade tem sido enfocada pelos ecólogos, com ênfase em estudos com macrófitas; ii) os prós e contras de vários métodos usados para quantificar a complexidade; iii) as consequências da estruturação de habitats proporcionada pelas macrófitas sobre invertebrados e peixes, assim como as possíveis causas, mediadas pela complexidade de habitats, que levam a alteraçóes nas assembléias desses animais; iv) os impactos potenciais de espécies exóticas invasoras de macrófitas sobre a complexidade de habitats e v) a importância da estrutura fornecida por macrófitas em estratégias de manejo visando à conservação da biodiversidade. Nós examinamos a literatura produzida tanto em regióes temperadas como tropicais, mas priorizamos essa última. Os principais resultados 
dessa revisão são resumidos a seguir. Houve grande variedade de medidas da complexidade de habitats em macrófitas que visam compreender sua influência sobre as assembléias de animais associadas a essas plantas. No entanto, a falta de padronização (considerando uma extensa variação de técnicas e escalas de resolução utilizadas) limita comparaçóes entre diferentes estudos que utilizam estruturas físicas simulando macrófitas ou plantas reais. As macrófitas afetam as assembléias de animais e promovem a biodiversidade através de uma cadeia de mecanismos decorrentes da complexidade estrutural de habitats, que envolvem a disponibilidade de abrigos e locais de alimentaçáo. Macrófitas exóticas invasoras podem modificar a estrutura de habitat e, assim, influenciar assembléias aquáticas. Nesse sentido, em muitos ecossistemas, essas plantas sáo o foco de estratégias de manejo objetivando a manutenção e restauração da biodiversidade.

Palavras-chave: vegetação aquática, espécies invasoras, diversidade, heterogeneidade de habitats.

\section{Introduction}

Macrophytes colonize many different types of aquatic ecosystems, such as lakes, reservoirs, wetlands, streams, rivers, marine environments and even rapids and falls (e.g., family Podostomaceae). This variety of colonized environments results from a set of adaptive strategies achieved over evolutionary time. Primary production of macrophytes can surpass that of other aquatic primary producers (Wetzel, 2001; Kalff, 2002). Macrophytes generally colonize shallow ecosystems where they become important components, influencing ecological processes (e.g., nutrient cycling) and attributes of other aquatic attached assemblages (e.g., species diversity).

Macrophytes affect nutrient cycling, for example through transference of chemical elements from sediment to water, by both active and passive processes (e.g., decomposition; Carignan and Kalff, 1980; Esteves and Camargo, 1986; Camargo et al., 2003). Limiting nutrients released by macrophytes, like phosphorus and nitrogen, are rapidly used by micro-algae and bacteria (which also use organic carbon released by macrophytes); these microorganisms may be free-living or attached to macrophyte surfaces and their detritus (Burkholder and Wetzel, 1990; Esteves and Camargo, 1986; Anésio et al., 2003; Rodrigues et al., 2003; Stets and Cotner, 2008). In addition, several species of macrophytes produce an elevated percentage of refractory matter (basically fibrous material) that is relatively slow to decompose (Bianchini Jr., 2003); thus, they also contribute to a return of carbon to sediment (Esteves, 1998). Macrophytes may also influence nutrient cycling in two other ways: retention of solids and nutrients by their submersed roots and leaves (Pott, VJ. and Pott, A., 2003; Meerhoff et al., 2003; Poi de Neiff et al., 1994) and reduction of nutrients released from sediment by protection against wind (and wave) action (Madsen et al., 2001). Moreover, this protection against waves also promotes the stabilization of shores and a reduction in erosion (Esteves, 1998). In addition, macrophytes may influence several other physicochemical properties of the water column. For example, conspicuous changes in oxygen, inorganic carbon, $\mathrm{pH}$ and alkalinity may result from their metabolism (Mack et al., 2000; Caraco and Cole, 2002).

Owing to their high rate of biomass production, macrophytes have primarily been characterized as an important food resource for aquatic organisms, providing both living (grazing food webs) and dead organic matter (detritivorous food webs). It is true that macrophytes may represent an important source of organic matter for aquatic herbivores and detritivores in some ecosystems (Duarte et al., 1994; Esteves, 1998; Poi de Neiff and Casco, 2003). However, this idea has been systematically rejected in most ecosystems after stable isotope studies, which have shown that algae, both freeliving and attached, are often more important than macrophytes in food webs (e.g., Araújo-Lima et al., 1986a; Lopes et al., 2007).

Independent of this controversy, from a purely biological point of view, macrophytes affect the structure of populations in addition to the diversity and composition of other aquatic assemblages. The effect of macrophytes on populations and communities has been widely demonstrated for a variety of organisms, such as micro- and macroinvertebrates (e.g., Bergström et al., 2000; Lansac-Tôha et al., 2003; Takeda et al., 2003), fish (Araújo-Lima et al., 1986b; Meschiatti et al., 2000; Vono and Barbosa, 2001; Agostinho et al., 2003; Theel et al., 2008) and waterbirds (Pott, VJ. and Pott, A., 2000; Guadagnin et al., 2009; Klaassen 
and Nolet, 2007). The role of macrophytes as physical structures that increase habitat complexity or heterogeneity in aquatic ecosystems is widely recognized. Within certain limits, comparing a water body lacking macrophytes (i.e., the pelagic zone) with one rich in macrophytes (i.e., the littoral zone) is the same as comparing a barren sand dune to a luxuriant forest (Scheffer, 2004). Thus, there must be a chain of mechanisms mediated by the habitat structure provided by macrophytes that affects animal abundance and biodiversity, where these can be observed at various temporal and spatial scales.

In this review, we have focused on questions related to habitat structural complexity provided by macrophytes. We first discuss how complexity has been viewed by ecologists, with an emphasis on those who have worked with macrophytes. Second, we show and discuss the pros and cons of several methods used to quantify plant complexity. Third, we consider the consequences of habitat structuring provided by macrophytes for invertebrates and fish, and the possible causes, mediated by habitat complexity, leading to changes in these animal assemblages. Finally, we consider the potential impact of non-native macrophyte species on habitat complexity and the importance of macrophyte management to maintain aquatic biodiversity. We examined literature produced both in temperate and tropical regions, but prioritized the latter.

\section{Habitat Complexity in Ecological Studies}

The use of habitat complexity (also termed "habitat heterogeneity" or several other termssee Tews et al., 2004 for a revision; but see Taniguchi et al., 2003 for a distinction between these terms) to explain differences in the structure and diversity of animal communities is well established in ecology. The first comprehensive studies of habitat complexity at finer spatial scales (the scales that we will mostly discuss here) occurred in the 1960s when MacArthur, RH. and MacArthur, JW. (1961) showed that foliage height diversity of forests positively affected bird species richness. In terrestrial ecosystems, $85 \%$ of studies show a positive relationship between animal diversity and habitat heterogeneity (Tews et al., 2004). The correlation between habitat heterogeneity and diversity is so evident that it has been used to explain diversity from microscales (e.g., rougosity at the leaf surface; Vieira et al., 2007) up to latitudinal gradients of diversity in terrestrial ecosystems (e.g., Gaston, 2000).
Most studies that have investigated macrophytes as components that enhance habitat complexity and influence other aquatic assemblages only make inferences about plant complexity in plant structure, but rarely measure this attribute. In general, these studies measure attributes of animal populations or assemblages residing in macrophyte beds (e.g., Delariva et al., 1994, Lansac-Tôha et al., 2003; Takeda et al., 2003), compare attributes among different beds (e.g., Araújo-Lima et al., 1986b; Delariva et al., 1994; Petry et al., 2003; Taniguchi et al., 2003) or compare attributes inside versus outside littoral zones (e.g., Dibble et al., 1996; Bergström et al., 2000; Okun and Mehner, 2005; Pelicice et al., 2005; Agostinho et al., 2007a). Thus, the lack of quantification of the structural complexity provided by aquatic macrophytes restricts comparisons among published data, allowing only inferences to be made from these investigations.

Few studies have measured habitat complexity provided by macrophytes or macrophytes together with other structures existent in littoral zones. For example, Vono and Barbosa (2001) measured the complexity of aquatic habitats by attributing relative values to several physical variables (tree branches and litter cover, rock cover and density and number of macrophyte life forms). Similarly, Petry et al. (2003) scaled the degree of complexity of aquatic habitats (0-5) based on the type of vegetation, compaction of macrophyte beds and structural patterns of stems and roots. Another approach is to compare aquatic assemblages colonizing macrophytes with "high" and "low" complexities (Taniguchi et al., 2003). Other even more accurate measurements of habitat complexity provided by macrophytes use stem and leaf densities (e.g., Theel et al., 2008), complexity indices (e.g., Dibble et al., 1996; 2006; Kovalenko et al., 2009), fractal dimension (e.g., Jeffries, 1993; Thomaz et al., 2008) or a combination of several different measurements (Warfe et al., 2008). Use of such discrepant methods produces results that are hard to compare, because methods may employ subjective measurements and the results are difficult to replicate. Thus, despite the presumed importance of habitat complexity provided by macrophytes to aquatic animal assemblages, there are no standardized methods to measure the spatial complexity of macrophytes (see Dibble et al., 2006; Dibble and Thomaz, 2009; Warfe et al., 2008).

An additional limitation regarding spatial complexity measurements concerns the spatial 
scale used. Most ecologists study intuitively familiar phenomena, and are therefore susceptible to approaching such phenomena on an anthropocentric scale in accordance with their experiences (Wiens, 1989). The degree of complexity realized (or measured) inside a macrophyte bed, on a scale of a few meters, may be adequate to explain attributes for populations or assemblages of small-bodied fish, but this scale would be inadequate for explaining macroinvertebrate assemblages, which certainly perceive (and use) the habitat quite differently (Dibble et al., 2006) (Figure 1). Such considerations about scales should be incorporated into studies aiming to explain ecological phenomena using habitat complexity as an explanatory factor (Wiens, 1989; Schneider, 2001).

In this way, standardization of habitat complexity measurements in aquatic macrophytes would allow studies to be comparable, providing more concise inferences when general patterns about structural complexity and attached assemblage relationships are the main goal. Such an availability of standardized results may contribute to modeling community processes and provide a basis for building new hypotheses about relationships between organisms and habitat complexity.

\section{Methods to Measure Spatial Complexity in Macrophytes}

Despite the evidence that macrophytes increase habitat heterogeneity and positively affect richness and composition of animal assemblages, most investigations ignore the measurement of heterogeneity or use non-systematic and difficult methods to compare measurements. These same shortcomings were also recognized for terrestrial studies trying to determine the effects of habitat heterogeneity on animal diversity, where the measurement of habitat heterogeneity was inconsistent, making comparisons among different studies very difficult (Tews et al., 2004).

Some of the types of studies inferring or truly testing the effects of macrophyte complexity on animal diversity and abundance, with their pros and cons, are summarized in Table 1. Investigations vary

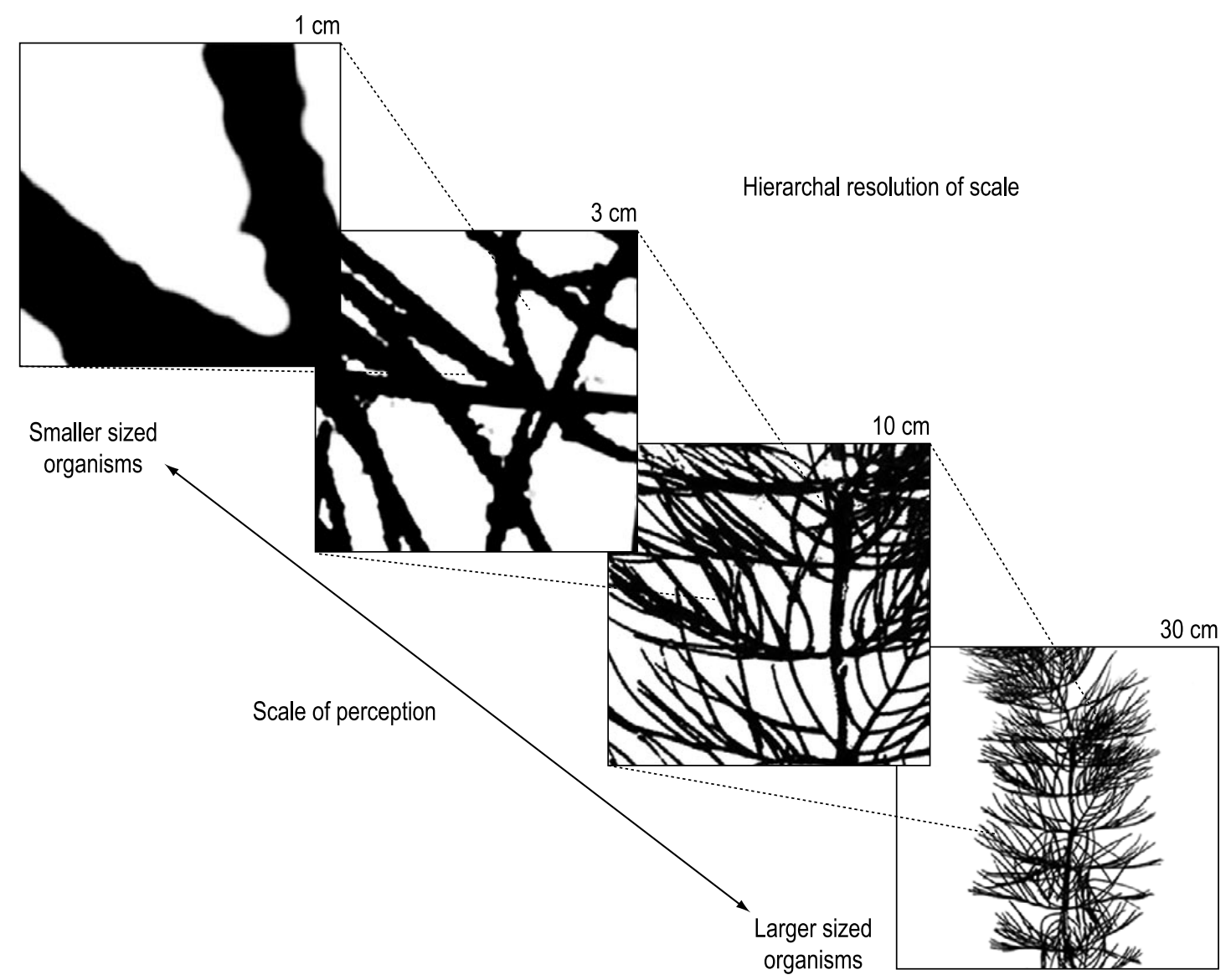

Figure 1. Different hierarchal scales within the aquatic macrophyte Myriophyllum spicatum showing different structural complexity at different scales. Based on Dibble et al. (2006). 
Table 1. Types of studies that measured the effect of macrophyte complexity on population and community attributes. Some references are given for each.

\begin{tabular}{|c|c|c|}
\hline Type of study and reference & Pros & Cons \\
\hline $\begin{array}{l}\text { Studies carried out only } \\
\text { inside littoral zones, comparing } \\
\text { different regions, lakes or beds } \\
\text { of plants with different } \\
\text { complexities }(1,2,3,4,5)\end{array}$ & $\begin{array}{l}\text { - use of real conditions } \\
\text { - comparison between size of beds } \\
\text { and different species of macrophytes } \\
\text { are possible }\end{array}$ & $\begin{array}{l}\text { - lack of control (open region, for example) } \\
\text { - habitat structure is rarely measured in these stud- } \\
\text { ies, although surrogates (plant biomass, abundance } \\
\text { etc.) may be used } \\
\text { - water physicochemistry may confound results }\end{array}$ \\
\hline $\begin{array}{l}\text { Studies comparing littoral with } \\
\text { pelagic zones }(6,7)\end{array}$ & $\begin{array}{l}\text { - open area is a control, espe- } \\
\text { cially when sampling is carried out } \\
\text { simultaneously } \\
\text { - comparisons between size of beds } \\
\text { and different species of macrophytes } \\
\text { against the open areas are possible }\end{array}$ & $\begin{array}{l}\text { - investigations still exploratory, without possibility of } \\
\text { using gradients of plant complexities, for example } \\
\text { - only the extreme comparisons between plant pres- } \\
\text { ence versus plant absence are done } \\
\text { - effects of complexity are still inferred (rarely } \\
\text { measured) } \\
\text { - water physicochemistry may also affect or con- } \\
\text { found the results }\end{array}$ \\
\hline $\begin{array}{l}\text { Studies using gradient of natural } \\
\text { plant complexities }(7,8,9)\end{array}$ & $\begin{array}{l}\text { - several levels of complexity (or } \\
\text { some surrogate) are measured } \\
\text { - relationship between complexity } \\
\text { and assemblage attributes, and their } \\
\text { modeling, are possible }\end{array}$ & $\begin{array}{l}\text { - complexity co-varies with other plant features, } \\
\text { such as surface area, plant age and chemical } \\
\text { composition } \\
\text { - water physicochemistry may also affect results, } \\
\text { confounding the results }\end{array}$ \\
\hline $\begin{array}{l}\text { Use of artificial structures with } \\
\text { different complexities }(10,11)\end{array}$ & $\begin{array}{l}\text { - allows control of all other confound- } \\
\text { ing factors } \\
\text { - relationship between complexity } \\
\text { and assemblage attributes, and their } \\
\text { modeling are possible }\end{array}$ & $\begin{array}{l}\text { - lacks reality } \\
\text { - can be used at very fine spatial scales (usually at } \\
\text { the leaf scale) }\end{array}$ \\
\hline
\end{tabular}

1) Lansac-Toha et al. (2003); 2) Takeda et al. (2003); 3) Delariva et al. (1994); 4) Pelicice et al. (2005); 5) Kovalenko et al. (2009); 6) Agostinho et al. (2007a); 7) Petry et al. (2003); 8) McAbendroth et al., 2005; 9) Thomaz et al. (2008); 10) Jeffries (1993); 11) Taniguchi et al. (2003).

from those exploring only littoral zones, which lack controls and are subject to all types of influences due to environmental variation, to those using artificial structures, which lack reality but control all other habitat and physicochemical conditions (Table 1).

The scale of observation of terrestrial habitat heterogeneity, and thus its measurement, depends on the taxonomic group, where this may vary from the architecture of a single plant leaf to the landscape (Tews et al., 2004). This same rationale applies for macrophytes in aquatic ecosystems. In this section, we will discuss some methods that we consider promising for measuring the structural complexity of macrophytes. Most of the measurements we chose are applied on fine spatial scales (centimeters to a few meters) and we believe that these are most appropriate for explaining attributes of assemblages of small - to medium-sized organisms (macroinvertebrates to small-bodied fish).

An index to measure plant complexity (or "architecture" as defined by the authors) was proposed by Dibble et al. (1996). This complexity index is based on frequency and length of interstices (empty spaces between leaves and stems) observed horizontally and vertically: architecture $=f h / l h+$ $f v / l v$, where: $f h=$ mean frequency or number of interstices intercepted along a distance $x$ in the horizontal axis; $l h=$ mean length of interstices along a distance $x$ in a horizontal axis; $f v=$ mean frequency or number of interstices intercepted along a distance $x$ in a vertical axis; $l v=$ mean length of interstices along a vertical axis (see a detailed example of the estimation of this index in Dibble et al., 2006). Elevated values indicate higher frequencies of smaller interstices, and thus higher physical (or spatial) complexity.

The use of this index has revealed great variation in complexity among Neotropical species of macrophytes (Dibble et al., 2006), and even among samples of the same species with different root densities (Padial et al., 2009). A great advantage of using an index like this one is that it provides the possibility for comparing different plants using a relatively direct, non-subjective, method. Gradients of diversity may be provided, allowing for the modeling of any response variable of interest (e.g., invertebrate or fish density and diversity). However, the use of pictures, and therefore only two dimensions, to infer three-dimensional complexity is one of its shortcomings. In addition, the spatial scale used significantly affects the results and different beds of macrophytes or different species of 
macrophytes are comparable only if measurements are made on the same scale (Dibble et al., 2006; see also Figure 1).

Another possibility for measuring macrophyte complexity is the use of fractal geometry. Fractals are based on the idea that any measurement attributed to an object (e.g., length, area or volume) depends on the appropriate notion of dimension (Sugihara and May, 1990). A fractal object is one whose measured structures repeat in a similar fashion on different spatial scales. The use of scaling laws or potential laws, like the fractal theory, were disseminated quickly in ecology after the 1980s (e.g., Enquist et al., 1999, 2003; Haskell et al., 2002). The strategy of measuring available spatial habitat using fractal geometry has great potential in ecology (Sugihara and May, 1990), and the fractal dimension (D) has already been used to describe, for example, habitat in different ecosystems and on different spatial scales, such as in landscapes (Schneider, 2001), tree assemblages (Morse et al., 1985), littoral zones (McAbendroth et al., 2005) and on a single macrophyte leaf, both artificial (Jeffries, 1993) and natural (Thomaz et al., 2008; Dibble and Thomaz, 2009).

The first investigation that used fractal geometry to measure the complexity of macrophytes on fine scales $(\mathrm{cm})$ was carried out with artificial plants (Jeffries, 1993). This author worked with plastic structures mimicking submersed plants with different fractal dimensions and used their complexity as an independent variable to explain attributes of the invertebrate assemblages. The finding was a positive relationship between fractal dimension and invertebrate density and taxa richness.

Fractal dimensions (D) can easily be determined by the box counting method. Before measurement, plants have to be photographed (black and white) at a specific scale, which should be the same for all plants to be compared. For macrophytes, it is recommended that the images used to determine $\mathrm{D}$ are transformed into silhouettes (using, for example, the program Microsoft PhotoEditor). Thus, D values become based on the structural perimeters exhibited by different plants, representing the degree of dissection and a boundary fractal that represented biological significance by estimating "edges" and differences among interstices characteristic of innate architecture in plant types (McAbendroth et al., 2005). Grids with different numbers of squares (e.g., 2, 4, 6, 8, 12, 16, 32, 64, 128 and 256) are superimposed, and the number of quadrats containing a plant structure is counted. The slope of $\log N(s)$ is plotted against $\log (1 / s)$, in which $s$ represents the scale of analysis and $N(s)$ the number of objects observed at that scale (see Dibble and Thomaz, 2009, for a detailed example). There are several free programs available for estimating $\mathrm{D}$ (e.g., FracTop v0.3b; Jelinek et al., 2003). Recent investigations have shown that $\mathrm{D}$ (as a measurement of plant complexity) significantly explains attributes of invertebrate assemblages associated with macrophytes, such as density, diversity, patterns of relative abundance and body size (Jeffries, 1993; Taniguchi et al., 2003; McAbendroth et al., 2005; Thomaz et al., 2008; Warfe et al., 2008; Dibble and Thomaz, 2009).

A more elaborate index that considers D values for individual plants, plant macrophyte density and macrophyte richness was recently proposed by McAbendroth et al. (2005) and Kovalenko et al. (2009). First, macrophytes are counted along transects at the surface and below the surface, and the average of these two readings is used as a measure of stem abundance. Then, habitat complexity is calculated as (Equation 1):

$C_{d}=\sum_{i=1}^{n} D_{i} N_{i}$

where Cd is the cumulative fractal habitat complexity, Di the plant fractal dimension, Ni the species abundance and $\mathrm{n}$ the number of plant species.

Some authors use surrogates of habitat structure. For example, Warfe et al. (2008) used three classes of indices to measure habitat physical structure: i) whole-plant attributes (surface area and plant volume); ii) interstitial space attributes (average space size and frequency, average refuge space from predation and total refuge space); in addition to iii) the degree of surface convolution at a range of scales of magnification (fractal dimension). Habitat structure provided by plants may also be estimated indirectly by simpler measurements; for example, by plant biomass, volume and proportional volume (i.e., percentage of macrophyte volume in the water column, e.g., Pelicice et al., 2008), by counting the number of plant structures per area or along a specific length (Theel et al., 2008; Cunha, 2009), by measuring plant height (Henry and Costa, 2003) or by the degree of structural clumping (Trochine et al., 2006). Regardless of the technique, estimates of complexity need to be appropriate for the organism being studied. Choosing a technique may involve balancing between some important aspects such as practicality and the ability to accurately represent 
of reality; the best choice of available techniques is the one that presents the most parsimonious aspects. For macroinvertebrates, for example, the interstitial index and the fractal dimension index were suggested as better surrogates for aquatic habitat complexity (Warfe et al., 2008).

However, we advise that measurements of plant complexity (or habitat heterogeneity) should usually be directly correlated with plant surface area, and that results should be interpreted with caution because increases in animal diversity or density may be an effect of area per se (the well known "species-area" and "abundances-area" effects) instead of complexity. This is especially true for organisms associated with macrophytes, like invertebrates and algae attached to plants. There are a few possibilities for overcoming this pitfall. Artificial structures have been used to control for plant area while simultaneously changing habitat complexity (e.g., Jeffries, 1993; Taniguchi et al., 2003; Vieira et al., 2007; Mormul, 2009; Figure 2). The use of artificial structures also overcomes other confounding effects that affect colonization of macrophytes by invertebrates, such as plant age, superficial grain, the chemical composition of leaves, and the release of allelopathic compounds.

An alternative method is to overcome confounding effects a posteriori using model

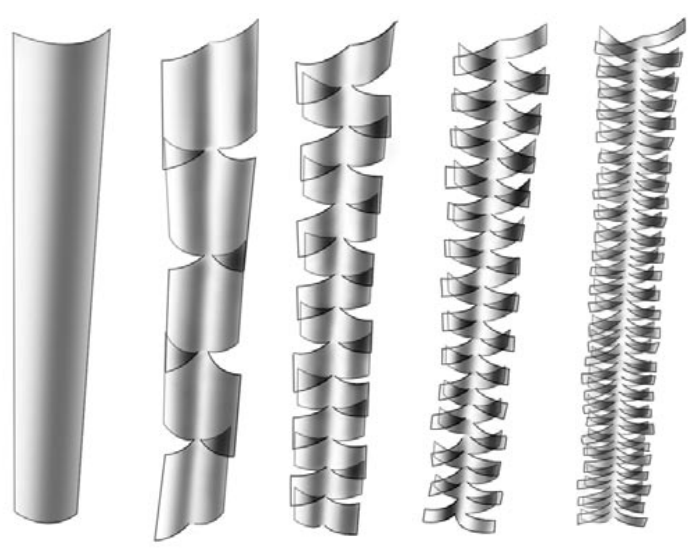

Figure 2. Schematic example of artificial structures built for aquatic invertebrate colonization. Artificial structures permit variation in complexity without altering superficial area or exposed time to attached organism's colonization, in addition to avoiding biological plant characteristics, such as differences in leaf roughness, chemical quality or allelopathic substances. Note that by being described by a scaling law, the increase in complexity with fractal dimension is not linear (small increases in $D$ results in great increases in complexity, especially at larger numbers, e.g., close to 2.0). Approximate fractal dimensions (from left to right): 1.1, 1.2, 1.3, 1.4 and 1.6. Based on Mormul (2009). selection, which allows the selection of variables that best explain the density and diversity of invertebrates and fish associated with macrophytes. For example, Thomaz et al. (2008) studied the effects of macrophyte leaf complexity on invertebrate density in six species of macrophytes. Because different plant species were used, at least three other variables, in addition to leaf complexity, could explain diversity: invertebrate abundance, leaf area and plant identity. Applying model selection (Akaike Information Criterion) they showed that the first model that best explained diversity was the one using invertebrate abundance, but the second one included abundance and leaf complexity. The use of model selection has been considered an advance (and even a philosophical change - Burnham and Anderson, 2002) in ecology because, besides being appropriate for exploratory results (which is usual in ecology), it gives to the researcher the possibility of choosing among several competitive models; the models that best explain the results, and that have ecological significance, are retained. However, we advise that the use of experiments whenever possible is preferable, because this is certain to control all confounding factors, such that the obtained results are certain to be due to plant complexity.

Finally, aerial photographs and remote sensing can be used to measure heterogeneity provided by macrophyte beds on very large spatial scales (Dibble et al., 1996; Guadagnin et al., 2009). Methods at these large spatial scales use the delineation of plant bed boundaries and the results can be used to extrapolate fish-plant relationships developed at microscale to larger spatial scales (Dibble et al., 1996).

Although our main objective in this section was to highlight some of the possibilities for measuring the habitat complexity provided by macrophytes, it is worth noting that species richness (a common response variable associated with plant complexity) should also be properly measured. A common mistake is to compare habitats with different complexities using raw species richness, i.e., the real number of species found in a sample. However, because species richness is highly dependent on abundance, the use of raw richness is a pitfall that usually produces incorrect results (see a discussion about this and other pitfalls in Gotelli and Colwell, 2001). Thus, rarefaction or other methods should be used to correct species richness and produce comparable results among samples.

In summary, owing to the variety of habitat complexity measurements, a method should be chosen with caution depending of the group of organisms investigated and the research questions to be addressed. Similarly, application may vary 
with scale, which should be considered in study designs. Finally, some perspectives to improve or enhance the accuracy of macrophyte complexity measurements include the use of fractal indices in three dimensions, which may represent a more realistic way to measure plant complexity.

\section{Consequences of Habitat Structuring on Aquatic Biota: the Effect of Spatial Scale}

Increases in the abundance and diversity of several attached faunal groups, in addition to changes in assemblage composition, are influenced by macrophyte complexities on several spatial scales. Dibble et al. (1996) suggested two spatial scales at which fish are analyzed: macroscale, referring to either an entire water body or zones of the same water body, and microscale, which includes plant complexity measured at scales perceived and exploited by fish. However, a wide range of scales could be identified and used if invertebrates and microorganisms are considered in addition to fish. For example, on a coarser spatial scale (e.g., among reservoirs in a same basin, $>10^{5} \mathrm{~km}^{2}$ ) there was a significant relationship between macrophyte diversity (an indication of habitat heterogeneity at the reservoir level) and the number of fish species (Agostinho et al., 2003). On a finer spatial scale (e.g., arms of the same reservoir, Itaipu, Brazil, with ca. $10^{3} \mathrm{~km}^{2}$ ) macrophyte cover also explained fish abundance, biomass, richness and diversity (Agostinho et al., 2003). Reducing the scale to a finer level (e.g., among beds in the same reservoir arm or within a single lake, ca. $10^{\circ} \mathrm{km}^{2}$ ), fish density and diversity were greatly influenced by submersed plant biomass and volume, two surrogates of complexity (Pelicice et al., 2005, 2008), or by patch complexity measured as a combination of fractal dimension, plant density and diversity (Kovalenko et al., 2010). On additional finer scales (e.g., among macrophyte beds of a small lake, $10^{-2}$ $\mathrm{km}^{2}$ ), plant complexity explained invertebrate densities and diversity (McAbendroth et al., 2005; Thomaz et al., 2008). Even plants located close to each other (spatial scale $<10^{-4} \mathrm{~km}^{2}-100 \mathrm{~m}^{2}$ ) differ in regard to attached invertebrate density and diversity, depending on plant structural complexity (Jeffries, 1993; Cunha, 2009; Thomaz et al., 2008). Finally, the effect of complexity on microorganisms has also been shown at even much finer scales (ca. $1 \times 10^{-12} \mathrm{~km}^{2}-10 \mathrm{~mm}^{2}$ ); for example, more complex artificial leaves (with veins of $0.01 \mathrm{~cm}$ tall) supported more species of testate amoeba than leaves without veins (Vieira et al., 2007). Thus, this simple literature survey shows investigations that support the effects of habitat complexity provided by macrophytes on organisms over at least 17 orders of magnitude $\left(10^{-12}-10^{5} \mathrm{~km}^{2}\right)$.

Structural complexity also significantly affects the size structure of animal populations and assemblages. In general, more complex habitats support higher densities and a greater diversity of small-bodied animals (Jeffries, 1993; McAbendroth et al., 2005; Thomaz et al., 2008). The notion of a mosaic behind this idea was first proposed by Hutchinson in 1959, in his classical "Homage to Santa Rosalia" (see Brown, 1981, for a discussion about this issue). In Hutchinson's own words:

The significance of such local diversity depends very largely on the size of the organisms under consideration [...] In qualitative terms the phenomenon can be exemplified by any of the larger species of ungulates which may require a number of different kinds of terrain within their home ranges, any one of which types of terrain might be the habitat of some small species."

Brown (1981) emphasized another part of "Homage," where Hutchinson argues that small organisms outnumber large ones because

\section{"[...] small size, by permitting animals to} become specialized to the conditions offered by small diversified elements in the environment mosaic, clearly makes possible a degree of diversity quite unknown among groups of larger organisms."

These ideas couple perfectly with the notion of a fractal-like nature to habitat complexity furnished by various inanimate (e.g., stones and

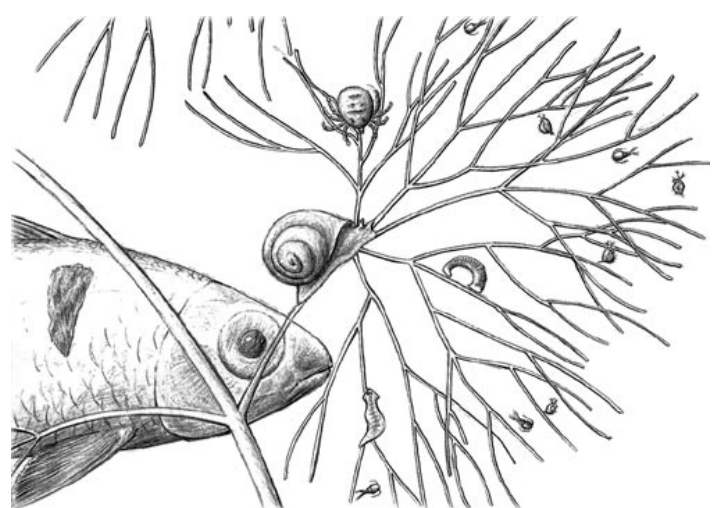

Figure 3. The "like fractal" characteristic of several macrophytes explains why there are more individuals (and species) of smaller organisms. There are more small spaces that can account for a higher number of smaller organisms. 
dead branches) and live objects, such as macrophytes (Figure 3).

By affecting groups of aquatic organisms differently, the structuring effects of macrophytes may propagate to several biotic mechanisms. For example, experiments involving phytoplankton, zooplankton and fish in sub-tropical lakes suggest that the role of free-floating plants as prey refugia and their effects on bottom-up and top-down mechanisms differ from those caused by submerged plants (Meerhof et al., 2003). According to these authors, even the fish category varies between these two groups of plants, with planktivorous fish preferring submersed and carnivorous fish preferring the roots of free-floating species.

Relationships in ecology can be identified on a variety of spatial scales, in which each degree of resolution may represent a different pattern of species versus habitat complexity relationship and may even influence ecological mechanisms. Therefore, standardization also in the scale of magnification may permit a broader way to explore results and propose new concepts.

\section{Why does Plant Complexity Increase Organism's Abundance and Diversity?}

The increase of animal abundance and diversity in littoral zones can be explained by a chain of events. First, submersed structures such as leaves, stems and roots provide a substrate for algae, other microorganisms and invertebrate attachment (Dibble et al., 1996; Rodrigues et al., 2003). Even emergent leaves and stems are important in this sense; for example, the abundance and richness of aerial spiders that use littoral zones are associated with complexity provided by macrophytes (Raizer and Amaral, 2001; Cunha, 2009). Habitat complexity provided by macrophytes is even more important for those web-building spiders, due to the great availability of physical structures for web attachment (Cunha, 2009). Second, structured habitats provide refuges for several invertebrates and small fish. Finally, microorganisms, invertebrates and small fish attract predators, which further increases the diversity inside macrophyte stands. A conceptual model incorporating these ideas is shown in Figure 4.

Considering only the submersed structures, the epiphyton (constituted by algae, bacteria and microinvertebrates) represents a source of food for fish and other invertebrates. The increase in algae abundance and organic matter in more complex structures could explain the attraction

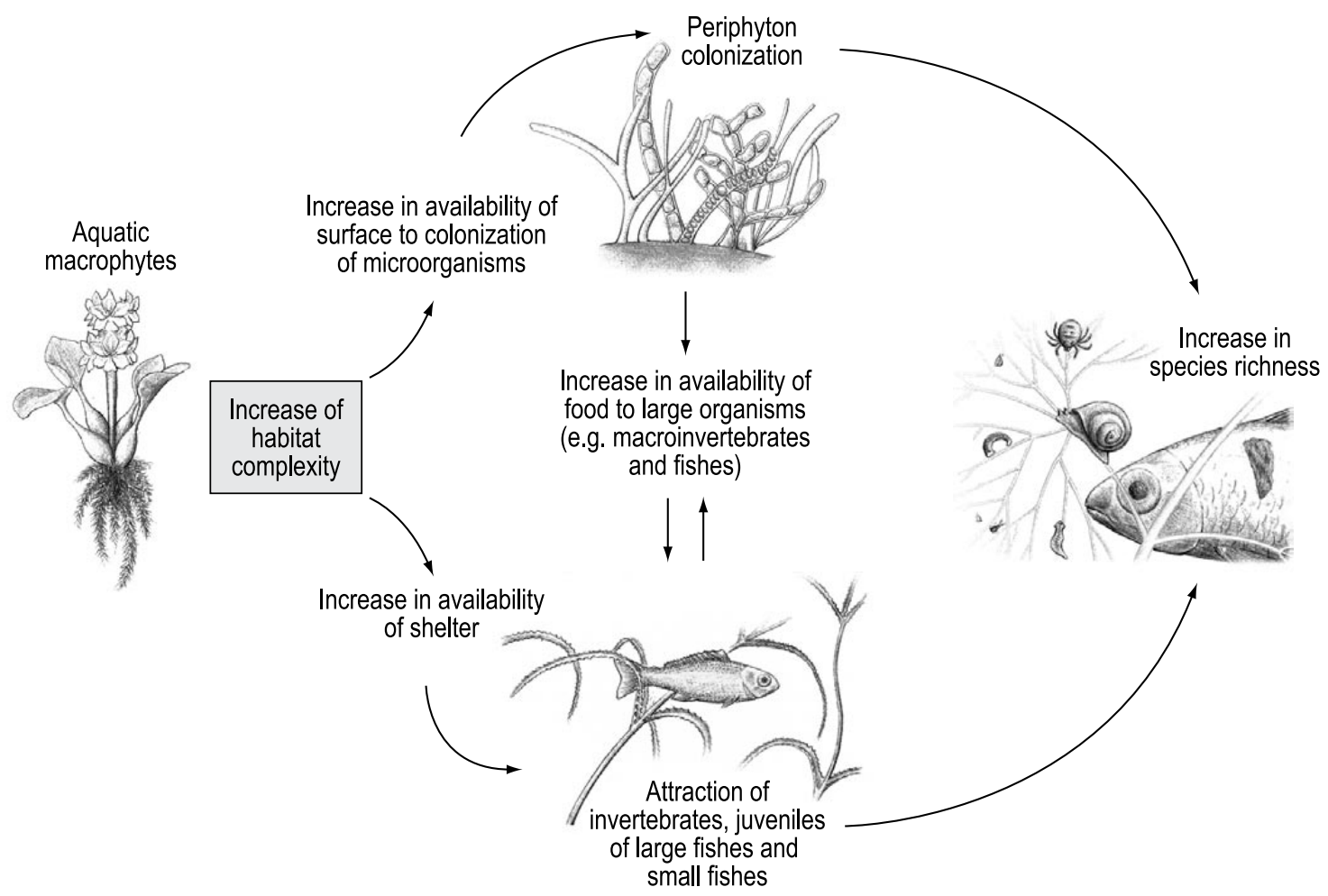

Figure 4. A conceptual model explaining why the structural complexity provided by macrophytes increases the diversity of other aquatic assemblages. 
of invertebrates, although contradictory results have been obtained (e.g., Taniguchi et al., 2003). Thus, we suggest that colonization by micro-algae, bacteria and other microorganisms represents a positive feedback on total abundance and diversity of macroinvertebrate and fish in the littoral zones; because it is possible that more complex habitats attract more microorganisms, these habitats would also be more attractive to their predators.

The importance of macrophytes as refugia (via an increase in habitat complexity) has been suggested for invertebrates and fish in field studies (Mazzeo et al., 2003; Okun and Mehner, 2005; Agostinho et al., 2007a), in mesocosm experiments (Meerhof et al., 2003), and has also been demonstrated experimentally in microcosms (Trochine et al., 2006; Padial et al., 2009). Refugia for Neotropical planktivoruous fish, for example, are better provided by submersed, compared to floating-leaved, macrophytes (Meerhof et al., 2003). Possibilities for shelter increase with such structural complexity and in the same way decrease visual contact among predators and their prey (Dibble et al., 1996).

Concerning predation, there are several studies showing that foraging changes in response to plant complexity. Based on a large literature synthesis about this issue, Dibble et al. (1996) have suggested that excessive barriers created by plants (in high complex beds of macrophytes) reduce the foraging efficiency and growth of fish; on the other hand, lack of habitat structuring provided by macrophytes increases competition and reduces fish growth. There are some Neotropical carnivorous fish whose behavior depends on structured habitats. For example, Hoplias malabaricus is a typical ambush predator that colonizes vegetated areas in tropical and sub-tropical ecosystems (Luz-Agostinho et al., 2008; Mazzeo et al., 2010). The foraging efficiency of invertebrates may also depend on habitat complexity (e.g., Trochine et al., 2006).

Thus, there seems to be a dual (and contradictory) effect of plant complexity, at least on fishes: on the one hand, more complex habitats provide more food for herbivores that feed on the epiphyton, and both the epiphyton and the associated predators attract more fish; on the other hand, extremely complex habitats represent a barrier for fish foraging. Consequently, we expect higher diversity of invertebrates and small fish on plants with intermediate levels of complexity. Interestingly, and in accordance to this hypothesis, it seems that at the scale of entire ecosystems (lakes), intermediate levels of plant coverage maximize fish densities and are optimal for growth and survival of fish (Dibble et al., 1996; Miranda and Hodges, 2000; Agostinho et al., 2007b).

Aspects of macrophyte complexity also mediate dynamics of fish reproduction (Dibble et al., 1996). Structural complexity may guarantee shelter to larvae and juvenile individuals, which are more susceptible to predation. These characteristics may explain the substantial occurrence of the initial development stages of fish on littoral zones colonized by macrophytes.

In summary, mechanisms mediated by habitat complexity affecting species assemblages associated with macrophytes are beyond simple interactions between species. Owing to various mechanisms acting simultaneously (like food availability, shelter and foraging sites), the effects of macrophyte complexity on assemblages may be synergistic and can only be comprehended though analyses encompassing several different mechanisms.

\section{Can Invasive Macrophytes Alter Community Structure Through Habitat Complexity?}

Biological invasions are currently a relevant subject when exploring biodiversity conservation (Gurevitch and Padilla, 2004). Development of technology in human society and facilitation of human displacement between different spots around the world have increased species introductions and invasions (Vitousek et al., 1997a, b; Mack et al., 2000). Aquatic macrophytes are often dispersed and introduced around the world for ornamental objectives, human feeding, mitigation of impacted areas and other anthropogenic interests (Kissman, 1997). When these plants have high potential for dispersal and reproduction, high development and plasticity (or flexibility according to Vermeij, 1996) they can be considered invasive species. Aquatic macrophytes as invasive species are widely recorded in the scientific literature (e.g., International Union for Conservation of Nature, 2003; Michelan et al., 2010; Thomaz et al., 2009; Barrientos and Allen, 2008; Bickel and Closs, 2008; Douglas and O'connor, 2003; Kelly and Hawes, 2005; Strayer et al., 2003).

In general, the first effects of macrophyte invasion include changes in the composition of the macrophyte assemblage itself (Mack et al., 2000; Michelan et al., 2010). Considering that aquatic macrophytes exert an important role in structuring habitats, their invasion could change the 
waterscape, impacting other taxonomic groups. In this way, alteration in assemblage due to changes in vegetation composition could extend to alteration in biotic relationships among species (Pearson, 2009; Bickel and Closs, 2008; Longepierre et al., 2005, Strayer, et al., 2003) and, in extreme circumstances, even cause species extinctions (McKinney and Lockwood, 1999; Clavero and García-Berthou, 2005).

Thus, effects due to invasion could firstly affect habitat heterogeneity provided to associated organisms, since the dominant characteristic achieved by invasive species in relation to native assemblages may be the increase of habitat homogenization. For example, habitat homogenization at small spatial scales ( $1 \mathrm{~m}^{2}$ quadrat) was shown after the invasion of the tropical signalgrass Urochloa subquadripara in several Brazilian ecosystems (Michelan et al., 2010). These authors showed that stands colonized by this grass were more similar in assemblage composition than those where it was absent. Homogenization in species composition can also imply an alteration in the physical structure of the habitat. The invasion of the macrophyte Schinus terebinthifolius for example, has radically transformed the Florida Everglades (USA) into dense stands of monocultures, causing devastating effects on the entire native biota (Mack et al., 2000). Within this homogenization perspective, it is possible to infer that, on a wider scale, beta and gamma diversity of organisms such as fishes and invertebrates can also be affected, due to decreases in shelter and foraging site variability.

Homogenization can hypothetically affect food web bases, once it influences food resource quality. For example, periphyton richness increases with macrophyte diversity, which can be assumed to be a surrogate for the physical and/or biological structure provided for colonization (for example an increase in Zygnemaphyceae species was shown by Murakami et al., 2009). Effects on the periphytic community and direct effects of habitat complexity (mainly refugia and foraging sites) mediate a chain of mechanisms that may affect other trophic levels; for example, epiphytic grazers may increase due to alteration in habitat structure, which could support an increase in provided sites to colonization by algae (Kelly and Hawes, 2005). Moreover, alteration in habitat structure could affect relative abundances of organisms. Strayer et al. (2003) found changes in invertebrate assemblage composition (both in epiphytic and benthos organisms) among Vallisneria americana (native) and Trapa natans (exotic), probably due to structural changes and reduced water movement. All of these changes are partially mediated by habitat complexity changes, such that dominance by invasive macrophytes may also affect communities via these mechanisms.

Although negative effects are always expected from species invasions, even neutral or positive results can be found (Kelly and Hawes, 2005), showing dichotomous effects for the invasion process. For example, habitat structure provided by invasive macrophyte beds can be increased in relation to native beds (through an increase in biomass, physical structuring and available area for organism colonization; e.g., Strayer et al., 2003; Barrientos and Allen, 2008), allowing greater epiphyton biomass, benthos invertebrate density and fish species occupation (Kelly and Hawes, 2005). For example, Lagarosiphon major, an invasive macrophyte, can play an important role for small fish species in shallow lakes because it resembles native species (Bickel and Closs, 2008). Similarly, an increase in habitat provided by Hydrilla verticillata has been followed by an increase in the number of ducks that feed on attached, well-structured habitats (Urban et al., 2006). Thus, positive effects of invasive species may be accentuated when they colonize sites lacking native macrophytes, increasing the habitat structure in these locations.

In other situations, the great similarity among non-native and native species does not promote associated assemblage changes. Comparing two aquatic macrophytes, one native and other exotic (both of the same family and presenting the same architectural structure), Mormul et al. (2010) found no differences between macroinvertebrate assemblages in relation to abundance, richness and Shannon-Winer diversity. In another investigation, the structural complexity provided by Urochloa mutica in relation to native macrophytes did not affect macroinvertebrate assemblage in a tropical floodplain in Australia (Douglas and O'Connor, 2003). In a similar way, a comparative study indicated that fish assemblage attributes (density, richness and diversity) did not differ among native plants and the invasive Hydrilla verticillata in a Mesoamerican lake, showing that, in this situation, the invasive macrophyte does not threaten assemblage of native organisms. In contrast, exotic beds showed increased total fish biomass (Barrientos and Allen, 2008).

Structural complexity may overcome other characteristics when invasion takes place, and nonnative species could still offer new possibilities for habitat exploration and, by a simple speculation, 
these species may contribute to biodiversity increases where they do not demonstrate invasiveness. Additionally, the effects of invasion have to be considered in light of the specific ways in which resource exploration could be different for each particular species.

Our discussion shows that alteration in habitat complexity has to be incorporated as a possible outcome of invasions by non-native species of macrophytes. Although invasions may enhance habitat complexity in some ecosystems, negative effects on native communities are expected when a single species dominates the community and leads the ecosystem to become less physically and biologically heterogeneous.

\section{How to use Complexity Provided by Macrophytes in Ecosystem Management?}

Management strategies have clear and planned objectives that aim to create progress in relation to a specific situation. Aquatic environments are generally subjected to several of these strategies, and their goals are often focused on human exploration, utilization or, more recently, the maintenance of biodiversity. In many of these cases, aquatic macrophytes may be the focus of these activities (Agostinho and Gomes, 1997; Melzer, 1999; Vereecken et al., 2006). Macrophytes require management when either too much or too little vegetation exists in an ecosystem for a given use (Johnstone, 1986)

Quite frequently, human activities (like excessive development, eradication or species introductions) can be directly or indirectly related to oscillations in aquatic plant populations, which can cause economic losses (for example, clogging of turbines, impracticability of navigation and recreational activities; Thomaz et al., 2003; Marcondes et al. 2003; Johnstone, 1986). Habitat losses due to alterations in aquatic plants may also occur that justify plant management.

The wide variety of functional types and potential amplitude of distribution typical of macrophytes (beyond exclusively aquatic environments, like the amphibian macrophytes) provides environmental structure in a range of habitats; directly or indirectly providing a great variety of physical structures. As previously discussed, habitat structure is fundamental to several aquatic assemblages that use macrophytes as shelter, reproduction and foraging sites (Delariva et al., 1994; Dibble et al., 1996, 2006; Taniguchi et al., 2003; Raizer and Amaral, 2001; Paillisson et al., 2006; Padial et al., 2009).
Thus, utilization of macrophytes for restoring degraded aquatic environments can contribute to the increase of structured habitats, which supports biodiversity recovery. Increases in macrophyte abundance can increase prey abundance. Considering macroinvertebrate biodiversity, for example, macrophytes assume an important role by providing habitat structural diversity. Such roles guarantee colonization and feeding sites (Gee et al., 1997), which may consequently enrich biodiversity of newly created or recently managed waterbodies. Such habitat structuring may favor, beyond shelter and foraging sites, species reproduction and emergence, providing for faster community regeneration (Painter, 1998). For example, in on-farm water storage the vegetated littoral zone may be more important to biodiversity than the total area of water storage owing to increases in macroinvertebrate richness attributed to complexity provided by aquatic macrophytes (Markwell and Fellows, 2008). These strategies can ensure biodiversity conservation even in such altered habitats.

Reservoirs have become increasingly common because of the demand for electrical energy. In Brazil, almost all energy comes from hydroelectric production. Striking consequences result from such activities, which can cause biodiversity losses and alteration in structural aspects of biological communities. Reservoir creation can promote increases in littoral zones, which are intensively colonized by aquatic macrophytes (Esteves, 1998). In this way, restoration of aquatic vegetation can play an important role in structuring habitats, affording foraging sites and shelter for many organisms (Castro and Arcifa, 1987; Delariva et al. 1994; Agostinho et al., 2003; Dibble et al., 2006), promoting community recovery. Like the findings already discussed, strong correlations have already been identified between submersed aquatic macrophyte biomass (a surrogate of habitat structure) and fish assemblage attributes (like density and richness) in Neotropical reservoirs (Pelicice et al., 2008).

On the other hand, aquatic macrophyte management sometimes involves removal of these plants and can be directed at controlling other species. For example, in the Brazilian shore of the Itaipu Reservoir, manual removal of Chara sp. decreased the abundance of piranha Serrasalmus marginatus, an aggressive fish that attacks bathers. This decrease in piranhas occurred because these fish rely on well-structured habitats to reproduce 
and rear their young. Thus, the goal intended by the management (reduce piranha populations in beaches) was achieved by altering habitat structure through removal of the aquatic vegetation (Fundação Universidade Estadual de Maringá, 1988; Agostinho et al., 2003). Despite that positive result, the loss in habitat structure also altered the whole fish assemblage, and there was a decrease in fish richness (from 25 to 10 species). In this example, both the decrease of "piranha" densities and fish richness were mediated by the loss of habitat structure provided by macrophytes.

Management actions are still directed at the control or eradication of invasive plants in natural environments in order to restore the original community (Bickel and Closs, 2008). Habitats colonized by invasive species can be subject to management actions when biodiversity is at risk (due to, for example, effects of the homogenization of habitats). These actions can be directed at the eradication of invasive species because of changes in habitat structure and consequently in the structure of other organisms' assemblages (Strayer et al., 2003).

Just as the establishment of these plants can have a harmful affect on associated organisms, changes and losses of species from the assemblage due to the removal of invasives and/or restoration of native macrophytes could cause a critical situation due to a new habitat alteration. Some studies have attempted to elucidate these interactions, which sometimes do not show negative impacts of invasive macrophytes. For example, Kovalenko et al. (2009) examined possible changes in fish foraging caused by the control of the invasive macrophyte Myriophyllum spicatum and found no changes in stomach fullness nor bluegill feeding selectivity and niche width. In the same way, management actions in the Skjern River (Denmark), where the invasive Glyceria maxima was replaced by Elodea canadensis and Sparganium sp., which increased total macrophyte coverage, was not identified as having a negative affect on invertebrate communities, suggesting that changes in the structure of habitats provided by macrophytes in this case were not damaging to the community (Pedersen et al., 2007).

The important role of macrophytes to fish assemblages is considered in techniques aimed at fisheries resource management (Agostinho et al., 2003; 2007b). Aquatic macrophytes may have a strong influence on the population dynamics of these organisms through structuring habitats. The absence of physical structures in the littoral zone of created ecosystems (like reservoirs) implies a lack of suitable habitats and the instability of biotic relationships, which may limit the resources available. This lack of structure can be identified as a limiting factor for population growth (Agostinho et al., 2007b). Thus, the presence of an intermediate level of cover of macrophytes may maintain populations and communities, ensuring support for a larger number of organisms (Dibble et al., 1996; Agostinho et al., $2003 ; 2007 b)$. This positive effect of macrophytes on fish is largely associated with the increase in habitat structuring in reservoirs. Thus, the presence of macrophytes is supposedly more important in reservoirs constructed in grasslands or in areas that had the vegetation removed before inundation because they lack habitat structure.

It is possible that a certain degree of structure of the environment promotes the recovery of fish stocks, ensuring that fisheries can operate with higher efficiency and profit. In recreational fisheries, results have already shown that macrophyte cover may reduce the amount of effort required to capture big largemouth bass (Maceina and Reeves, 1996). On the other hand, excessive macrophyte cover can reduce capture effort (Slipke et al., 1998).

The examples discussed here show that strategies aimed at managing macrophyte assemblages can be considered as tools to improve habitat structure, maintain biodiversity of several assemblages and sustain fisheries in freshwater bodies. Despite the high management requirements in freshwater ecosystems, details behind the mechanisms are not yet clearly known, so particular local aspects should be considered whenever possible (Hauxwell et al., 2004). Thus, it is necessary to search for models that incorporate the combined use of natural resources both for nature conservation and for sustainable use (Van Nes et al., 2002). In any instance, management strategies using macrophytes are based on the general concept that these plants increase habitat complexity, which, in turn, brings benefits for the aquatic and semi-aquatic biota.

Aquatic macrophytes are an important tool for habitat management that involves economic human interests to the restoration of natural biota. Increases in habitat complexity allow for species enrichment due to increases in possibilities of habitat exploration and niche opportunities. All these aspects are in accordance with human interests that vary across a broad range of possibilities, from purely economic interests to concerns about biodiversity restoration. 


\section{Main Conclusions and Perspectives}

Aquatic macrophytes have been shown to be important habitat structurers, are highly influential on the composition of the associated fauna and influence interspecific relationships. Increases in animal abundance, richness and diversity due to macrophyte habitat complexity may be explained by simple mechanisms that involve the availability of habitat, which increases the possibility of available food and consequently attracts other organisms, which then relate to each other while utilizing this complexity as shelter or foraging sites. Although a large number of studies have attempted to identify relationships between macrophyte structural complexity and their associated organisms, a great pitfall is the lack of standardization in techniques and the use of inappropriate spatial scales in these investigations. Invasive aquatic macrophytes are of concern because they cay lead to "habitat homogenization," which directly affects native flora and fauna. Despite this, structural complexity provided by invasive macrophytes may increase habitat complexity in certain ecosystems and consequently increase attached assemblage attributes like abundance and richness. Providing such an important role in aquatic assemblage structure, aquatic macrophytes may also be used as a management tool, taking into account biodiversity restoration and even human economic interest.

\section{Acknowledgements}

S. M. Thomaz is especially thankful to CNPq for continuous funding through a Research Productivity Grant and E. R. Cunha acknowledges the "Coordenadoria de Aperfeiçoamento de Pessoal de Nível Superior" (CAPES) for providing a MSc. scholarship.

\section{References}

AGOSTINHO, AA. and GOMES, LC. 1997. Manejo e monitoramento de recursos pesqueiros: perspectivas para o reservatório de Segredo. In AGOSTINHO, AA. and GOMES, LC., ed. Reservatório de Segredo: bases ecológicas para o manejo. Maringá: Eduem. p. 319-364.

AGOSTINHO, AA., GOMES, LC. and JULIO Jr., HF. 2003. Relaçóes entre macrófitas aquáticas e fauna de peixes. In THOMAZ, SM. and BINI, LM., eds. Ecologia e Manejo de Macrófitas Aquáticas. Maringá: Eduem. p. 261-280.

AGOSTINHO, AA., GOMES, LC. and PELICICE, FM. 2007b. Ecologia e manejo de recursos pesqueiros em reservatórios do Brasil. Maringá: Eduem. p. 501.

AGOSTINHO, AA., THOMAZ, SM., GOMES, LC. and BALTAR, SLSMA. 2007a. Influence of the macrophyte Eichhornia azurea on fish assemblage of the Upper Paraná River floodplain (Brazil). Aquatic Ecology, vol. 41, p. 611-619.

ANESIO, AM., ABREU, PC. and BIDDANDA, BA. 2003. The role of free and attached microorganisms in the decomposition of estuarine macrophyte detritus. Estuarine, Coastal and Shelf Science, vol. 56, no. 2, p. 197-201.

ARAÚJO-LIMA, CARM., FORSBERG, BR., VICTORIA, R. and MARGINELLI, L. 1986a. Energy-sources for detritivorous fishes in the Amazon. Science, vol. 234, p. 1256-1258.

ARAÚJO-LIMA, CARM., PORTUGAL, LPS. and FERREIRA, EG. 1986b. Fish-macrophyte relationship in the Anavilhanas Archipelago, a black water system in the Central Amazon. Journal of Fish Biology, vol. 29, p. 1-11.

BARRIENTOS, CA. and ALLEN, MS. 2008. Fish abundance and community composition in native and non-native plants following hydrilla colonization at Lake Izabal, Guatemala. Fisheries Management and Ecology, vol. 15, no. 2, p. 99-106.

BERGSTRÖM, SE., SVENSSON, JE. and WESTBERG, E. 2000. Habitat distribution of zooplankton in relation to macrophytes in an eutrophic lake. Verhandlungen des Internationalen Verein Limnologie, vol. 27, p. 2861-2864.

BIANCHINI Jr, I. 2003. Modelos de crescimento e decomposição de macrófitas aquáticas. In THOMAZ, SM. and BINI, LM., ed. Ecologia e Manejo de Macrófitas Aquáticas. Maringá: Eduem. p. 85-126.

BICKEL, TO. and CLOSS, GP. 2008. Fish distribution and diet in relation to the invasive macrophyte Lagarosiphon major in the littoral zone of Lake Dunstan, New Zealand. Ecology of Freshwater Fish, vol. 17, no. 1, p. 10-19.

BROWN, JH. 1981. Two decades of Homage to Santa Rosalia: toward a general theory of diversity. American Zoologist, vol. 21, p. 877-888.

BURKHOLDER, JA. and WETZEL, RG. 1990. Epiphitic microalgae on natural substrata in a hardwater lake: seasonal dynamics of community structure, biomass and ATP content. Archif für Hydrobiologie, vol. 83, p. 1-56.

BURNHAM, KP. and ANDERSON, DR. 2002. Model Selection and Multimodel Inference. $2^{\text {nd }}$ ed. New York: Springer-Verlag. 488 p. 
CAMARGO, AFM., PEZZATO, MM. and HENRYSILVA, GG. 2003. Fatores limitantes à produção primária de macrófitas aquáticas. In THOMAZ, SM. and BINI, LM., ed. Ecologia e Manejo de Macrófitas Aquáticas. Maringá: Eduem. p. 59-83.

CARACO, NF. and COLE, JJ. 2002. Contrasting impacts of a native and alien macrophyte on dissolved oxygen in a large river. Ecoogical Applications, vol. 12, no. 5, p. 1496-1509.

CARIGNAN, R. and KALFF, J. 1980. Phosphorus Sources for Aquatic Weeds: Water or Sediments? Science, vol. 207, no. 4434, p. 987-989.

CASTRO, RMC. and ARCIFA, MS. 1987. Comunidades de peixes de reservatórios no sul do Brasil. Revista Brasileira de Biologia, vol. 47, no. 4, p. 493-500.

CLAVERO, M. and GARCÍA-BERTHOU, E. 2005. Invasive species are a leading cause of animal extinctions. Trends in Ecology and Evolution, vol. 20, no. 3, p. 110.

CUNHA, ER. 2009. Efeito da complexidade estrutural de três espécies de macrófitas aquáticas sobre atributos da assembleia de aranhas (Arachnida, Araneae) em uma área alagável tropical. Maringá: Universidade Estadual de Maringá - UEM. [Graduation Monograph in Biological Sciences].

DELARIVA, RL., AGOSTINHO, AA., NAKATANI, K. and BAUMGARTNER, G. 1994. Ichthyofauna associated to aquatic macrophytes in the upper Paraná River floodplain. Revista UNIMAR, vol. 16, p. 41-60.

DIBBLE, ED. and THOMAZ, SM. 2009. Use of fractal dimension to assess habitat complexity and its influence on dominant invertebrates inhabiting tropical and temperate macrophytes. Journal of Freshwater Ecology, vol. 24, p. 93-102.

DIBBLE, ED., KILLGORE, KJ. and DICK, GO. 1996. Measurement of plant architecture in seven aquatic plants. Journal of Freshwater Ecology, vol. 11, p. 311-318.

DIBBLE, ED., THOMAZ, SM. and PADIAL, AA. 2006. Spatial complexity measured at a multi-scale in three aquatic plant species. Journal of Freshwater Ecology, vol. 21, no. 2, p. 239-247.

DOUGLAS, MM. and O'CONNOR, R. 2003. Effects of the exotic macrophyte, paragrass (Urochloa mutica), on benthic and epiphytic macroinvertebrates of a tropical floodplain. Freshwater Biology, vol. 48, no. 6, p. 962-971.

DUARTE, CM., PLANAS, D. and PEÑUELAS, J. 1994. Macrophytes, taking control of an ancestor home. In MARGALEF, R., ed. Limnology now: a paradigm of planetary problems. Amsterdam: Elsevier. p. 59-79.
ENQUIST, BJ., ECONOMO, EP., HUXMAN, TE., ALLEN, AP., IGNACE, DD. and GILLOOLY, JF. 2003. Scaling metabolism from organisms to ecosystems. Nature, vol. 423, p. 639-642.

ENQUIST, BJ., WEST, GB., CHARNOV, EL. and BROWN, JH. 1999. Allometric scaling of production and life history variation in vascular plants. Nature, vol. 401, p. 907-911.

ESTEVES, FA. 1998. Fundamentos de limnologia. 2. ed. Rio de Janeiro: Interciência. 602 p.

ESTEVES, FA. and CAMARGO, AFM. 1986. Sobre o Papel das Macrofitas Aquaticas na Estocagem e Ciclagem de Nutrientes. Acta Limnologica Brasiliensia, vol. 1, p. 273-298.

Fundação Universidade Estadual de Maringá. 1988. Nupélia/Itaipu Binacional. Levantamento ictiofaunistico na prainha de Santa Helena (periodo: 12-13 de janeiro/88). Maringá. 17 p.

GASTON, KJ. 2000. Global patterns in biodiversity. Nature, vol. 405, p. 220-227.

GEE, JR., SMITH, BD., LEE, KM. and GRIFFITHS, SW. The ecological basis of freshwater pond management for biodiversity. Aquatic Conservation, 1997, vol. 7, p. 91-104.

GOTELLI, NJ. and COLWELL RK. 2001. Quantifying biodiversity: procedures and pitfalls in the measurement and comparison of species richness. Ecology Letters, vol. 4, p. 379-391.

GUADAGNIN, DL., MALTCHIK, L. and FONSECA, CR. 2009. Species-area relationship of Neotropical waterbird assemblages in remnant wetlands: looking at the mechanisms. Diversity and Distributions, vol. 15, p. 319-327.

GUREVITCH, J. and PADILLA, D. 2004. Are invasive species a major cause of extinctions? Trends in Ecology and Evolution, vol. 19, no. 9, p. 470-474.

HASKELL JP., RITCHIE, ME. and OLFF, $H$. Fractal geometry predicts varying body size scaling relationships for mammal and bird home ranges. Nature, 2002, vol. 418, p. 527-530.

HAUXWELL, J., OSENBERG, CW. and FRAZER, TK. 2004. Conflicting management goals: Manatees and invasive competitors inhibit restoration of a native macrophyte. Ecological Applications, vol. 14, no. 2, p. 571-586.

HENRY, R. and COSTA, MLR. 2003. As macrófitas como fator de heterogeneidade espacial, um estudo em três lagoas com diferentes conectividades com o rio Paranapanema. In THOMAZ, SM. and BINI, LM., ed. Ecologia e Manejo de Macrófitas Aquáticas. Maringá: Eduem. p. 189-210. 
HUTCHINSON, GE. 1959. Homage to santa Rosália, or why are there so many kinds of animals? American Naturalist, vol. 93, p. 117-125.

International Union for Conservation of Nature IUCN. 2003. 100 of the world's worst invasive alien species. Aukcland, New Zeland: Invasive Species Specialist Grup.

JEFFRIES, M. 1993. Invertebrate colonization of artificial pondweeds of differing fractal dimension. Oikos, vol. 67, no. 1, p. 142-148.

JELINEK, H., CORNFORTH, D. and WEYMOUTH, L. 2003. FracTopv.0.3b. Available from: <http://seal.tst.adfa.edu.au/ s3165516/ Fractop>. Access in: April 4, 2010.

JOHNSTONE, IM. 1986. Macrophyte management: an integrated perspective. New Zealand Journal of Marine and Freshwater Research, vol. 20, p. 599-614.

KALFF, J. 2002. Limnology. New Jersey: Printice Hall. 592 p.

KELLY, DJ. and HAWES, I. 2005. Effects of invasive macrophytes on littoral-zone productivity and foodweb dynamics in a New Zealand high-country lake. Journal of the North American Benthological Society, vol. 24, no. 2, p. 300-320.

KISSMAN KG. 1997. Plantas infestantes e Nocivas, Tomo I, 2a edn. Sáo Paulo: Editora BASF. $825 \mathrm{p}$.

KLAASSEN, M. and NOLET, BA. 2007. The role of herbivorous water birds in aquatic systems through interactions with aquatic macrophytes, with special reference to the Bewick's Swan-Fennel Pondweed system. Hydrobiologia, vol. 584, p. 205-213.

KOVALENKO, K., DIBBLE, ED. and FUGI, R. 2009. Fish feeding in changing habitats: effects of invasive macrophyte control and habitat complexity. Ecology of Freshwater Fish, vol. 18, no. 2, p. 305-313.

KOVALENKO, K., DIBBLE, ED. and SLADE, JG. 2010. Community effects of invasive macrophyte control: role of invasive plant abundance and habitat complexity. The Journal of Applied Ecology, vol. 47, p. 318-328.

LANSAC-TÔHA, FA., VELHO, LFM. and BONECKER, CC. 2003. Influência de macrófitas aquáticas sobre a estrutura da comunidade zooplanctônica. In: THOMAZ, SM. and BINI, LM., ed. Ecologia e Manejo de Macrófitas Aquáticas. Maringá: Eduem. p. 231-243.

LONGEPIERRE, S., ROBERT, A., LEVI, F. and FRANCOUR, P. 2005. How an invasive alga species (Caulerpa taxifolia) induces changes in foraging strategies of the benthivorous fish
Mullussur muletus in coastal Mediterranean ecosystems. Biodiversity and Conservation, vol. 14, no. 2, p. 365-376.

LOPES, CA., BENEDITO-CECILIO, E. and MARTINELLI, LA. 2007. Variability in the carbon isotope signature of Prochilodus lineatus (Prochilodontidae, Characiformes) a bottomfeeding fsh of the Neotropical region. Journal of Fish Biology, vol. 70, p. 1649-1659.

LUZ-AGOSTINHO, KDG., AGOSTINHO, AA., GOMES, LC. and JÚLIO JÚNIOR, HF. Influence of flood pulses on diet composition and trophic relationships among piscivorous fish in the upper Paraná River floodplain. Hydrobiologia, vol. 607, p. 187-198.

MACARTHUR, RH. and MACARTHUR, JW. 2008. On Bird Species Diversity. 1961, Ecology, vol. 42, p. 594-598.

MACEINA, MJ. and REEVES, WC. 1996. Relations between submersed macrophyte abundance and largemouth bass tournament success on two tennessee River impoundments. Journal of Aquatic Plant Management, vol. 34, p. 33-38.

MACK, RN., SIMBERLOFF, D., LONSDALE, WM., EVANS, H., CLOUT, M. and BAZZAZ, FA. 2000. Biotic Invasions: Causes, Epidemiology, Global Consequences and Control. Issues in Ecology, vol. 10, no. 3, p. 689-710.

MADSEN JD., CHAMBERS, PA. and JAMES, WF. 2001. The interaction between water movement, sediment dynamics and submersed macrophytes. Hydrobiologia, vol. 444, no. 1-3, p. 71-84.

MARCONDES, DAS., MUSTAFÁ, AL. and TANAKA, RH. 2003. Estudos para manejo integrado de plantas aquáticas no reservatório de Jupiá. In THOMAZ, SM. and BINI, LM., eds. Ecologia e Manejo de Macrófitas Aquáticas. Maringá: Eduem. p. 299-317.

MARKWELL, KA. and FELLOWS, CS. 2008. Habitat and Biodiversity of On-Farm Water Storages: a Case Study in Southeast Queens land, Australia. Environmental Management, vol. 41, p. 234-249.

MAZZEO, N., IGLESIAS, C., TEIXEIRA DE MELO, F., BORTHAGARAY, A., FOSALBA, C., BALLABIO, R., LARREA, D., VILCHES, J., GARCÍA, S., PACHEGO, JP. and JEPPESEN, E. 2010. Trophic cascade effects of Hoplias malabaricus (Characiformes, Erythrinidae) in subtropical lakes food webs: a mesocosm approach. Hydrobiologia, vol. 644, no. 1, p. 325-335.

MAZZEO, N., RODRÍGUEZ-GALLEGO, L., KRUK, C., MEERHOFF, M., GORGAL, J. and LACEROT, G. 2003. Effects of Egeria densa 
Planch. beds on a shallow lake without piscivorous fish. Hydrobiologia, vol. 506-509, p. 591-602.

McABENDROTH, L., RAMSAY, PM., FOGGO, A., RUNDLE, SD. and BILTON, DT. 2005. Does macrophytes fractal complexity drive invertebrate diversity, biomass and body size distributions? Oikos, vol. 111, no. 2, p. 279-290.

McKINNEY, ML. and LOCKWOOD, JL. 1999. Biotic homogenization: a few winners replacing many losers in the next mass extinction. Trends in Ecology \& Evolution, vol. 14, no. 11, p. 450-453.

MEERHOFF, M., MAZZEO, N., MOSS, B. and RODRÍGUEZ-GALLEGO, L. 2003. The structuring role of free-floating versus submerged plants in a subtropical shallow lake. Aquatic Ecology, vol. 37, p. 377-391.

MELZER, A. 1999. Aquatic macrophytes as tools for lake management. Hydrobiologia, vol. 395/396, p. 181-190.

MESCHIATTI, AJ., ARCIFA, MS. and FENERICHVERANI, N. 2000. Fish communities associated with macrophytes in Brazilian floodplain lakes. Environmental Biology of Fish, vol. 58, p. 133-143.

MICHELAN, TS., THOMAZ, SM., MORMUL, RP. and CARVALHO, P. 2010. Effects of an exotic-invasive macrophyte (tropical signalgrass) on native plant community composition, species richness and functional diversity. Freshwater Biology, vol. 55, no. 6, p. 1315-1326.

MIRANDA, LE. and HODGES, KB. 2000. Role of aquatic vegetation coverage on hypoxia and sunfish abundance in bays of a eutrophic reservoir. Hydrobiologia, vol. 427, p. 51-57.

MORMUL, RP. 2009. Efeito da complexidade estrutural e da distância da fonte de dispersáo sobre a abundância e diversidade de invertebrados: um experimento com macrófitas artificiais. Maringá: Universidade Estadual de Maringá - UEM. [Master Thesis in Ambiental Sciences].

MORMUL, RP., THOMAZ, SM., HIGUTI, J. and MARTENS, K. 2010. Ostracod (Crustacea) colonization of a native and a non-native macrophyte species of Hydrocharitaceae in the Upper Paraná floodplain (Brazil): an experimental evaluation. Hydrobiologia, vol. 644, p. 185-193.

MORSE, DR., LAWTON, JH., DODSON, MM. and WILLIAMSON, MH. 1985. Fractal dimension of vegetation and the distribution of arthropod body lengths. Nature, vol. 314, p. 731-732.

MURAKAMI, EA., BICUDO, DC. and RODRIGUES, L. 2009. Periphytic algae of the Garças Lake, Upper Paraná River foodplain: comparing the years 1994 and 2004. Brazilian Journal of Biology, vol. 69, p. 459-468.

OKUN, N. and MEHNER, T. 2005. Distribution and feeding of juvenile fish on invertebrates in littoral reed (Phragmites) stands. Ecology of Freshwater Fish, vol. 14, p. 139-149.

PADIAL, AA., THOMAZ, SM. and AGOSTINHO, AA. 2009. Effects of structural heterogeneity provided by the floating macrophyte Eichhornia azurea on the predation efficiency and habitat use of the small Neotropical fish Moenkhausia sanctaeflomenae. Hydrobiologia, vol. 624, p. 161-170.

PAILLISSON, JM., REEBER, S., CARPENTIER, A. and MARION, L. 2006. Plant-water regime management in a wetland: consequences for a floating vegetation-nesting bird, whiskered tern Chlidonias hybridus. Biodiversity and Conservation, vol. 15, p. 3469-3480.

PAINTER, D. 1998. Effects of ditch management patterns on Odonata at Wicken Fen, Cambridgeshire, UK. Biological Conservation, vol. 84, p. 189-195.

PEARSON, DE. 2009. Invasive plant architecture alters trophic interactions by changing predator abundance and behavior. Oecologia, vol. 159, p. 549-558.

PEDERSEN, ML., FRIBERG, N., SKRIVER, J., BAATTRUP-PEDERSEN, A. and LARSEN, SE. 2007. Restoration of Skjern River and its valleyShort-term effects on river habitats, macrophytes and macroinvertebrates. Ecological Engineering, vol. 30, p. 145-156.

PELICICE, FM., AGOSTINHO, AA. and THOMAZ, SM. 2005. Fish assemblages associated with Egeria in a tropical reservoir: Investigating the effects of plant biomass and diel period. Acta Oecologica, vol. 27, p. 9-16.

PELICICE, FM., THOMAZ, SM. and AGOSTINHO, AA. 2008. Simple relationships to predict attributes of fish assemblages in patches of submerged macrophytes. Neotropical Ichthyology, vol. 6, p. 543-550.

PETRY, P., BAYLEY, PB. and MARKLE, DF. 2003. Relationships between fish assemblages, macrophytes and environmental gradients in the Amazon River Floodplain. Journal of Fish Biology, vol. 63, p. 547-579.

POI DE NEIFF, AS. and CASCO, SL. 2003. Biological agents that accelerate winter decay of Eichhornia crassipes Mart. Solms. in northeastern Argentina. In THOMAZ, SM. and BINI, LM., ed. Ecologia e Manejo de Macrófitas Aquáticas. Maringá: Eduem. p. 127-144. 
POI DE NEIFF, ASG., NEIFF, JJ., ORFEO, O. and CARIGNAN, R. 1994. Quantitative importance of particulate matter retention by the roots of Eichhornia crassipes in the Paraná floodplain. Aquatic Botany, vol. 47, no. 3-4, p. 213-223.

POTT, VJ. and POTT, A. 2000. Plantas aquáticas do Pantanal. Brasília, DF: Embrapa. 404 p.

POTT, VJ. and POTT, A. 2003. Dinâmica da vegetação aquática do Pantanal. In THOMAZ, SM. and BINI, LM., ed. Ecologia e Manejo de Macrófitas Aquáticas. Maringá: Eduem. p. 145-162.

RAIZER, J. and AMARAL, MEC. 2001. Does the structural complexity of aquatic macrophytes explain the diversity of associated spider assemblages? Journal of Arachnology, vol. 29, p. 227-237.

RODRIGUES, L., BICUDO, DC. and MOSCHINICARLOS, V. 2003. O papel do perifíton em áreas alagáveis e nos diagnósticos ambientais. In THOMAZ, SM. and BINI, LM., ed. Ecologia e Manejo de Macrófitas Aquáticas. Maringá: Eduem. p. 211-230.

SCHEFFER, M. 2004. Ecology of shallow lakes. Norwell: Kluwer Academic Publishers. 357 p.

SCHNEIDER, DC. 2001. The rise of the concept of scale in ecology. BioScience, vol. 51, p. 545-553.

SLIPKE, JW., MACEINA, MJ. and GRIZZLE, JM. 1998. Analysis of the recreational fishery and angler attitudes toward Hydrilla in lake seminole, a southeastern reservoir. Journal of Aquatic Plant Management, vol. 36, p. 101-107.

STETS, EG. and COTNER, JB. 2008. Littoral zones as sources of biodegradable dissolved organic carbon in lakes. Canadian Journal of fisheries and Aquatic Science, vol. 65, no. 11, p. 2454-2460.

STRAYER, DL., LUTZ, C., MALCOM, HM., MUNGER, K. and SHAW, WH. 2003. Invertebrate communities associated with a native (Vallisneria americana) and an alien (Trapa natans) macrophyte in a large river. Freshwater Biology, vol. 48, p. 1938-1949.

SUGIHARA, G. and MAY, RM. 1990. Applications of fractals in ecology. Trends in Ecology and Evolution, vol. 5, p. 79-86.

TAKEDA, AM., SOUZA-FRANCO, GM., MELO, SM. and MONKOLSKI, A. 2003. Invertebrados associados às macrófitas aquáticas da planície de inundação do alto rio Paraná (Brasil). In THOMAZ, SM. and BINI, LM., ed. Ecologia e Manejo de Macrófitas Aquáticas. Maringá: Eduem.

TANIGUCHI, H., NAKANO, S. and TOKESHI, M. 2003. Influences of habitat complexity on the diversity and abundance of epiphytic invertebrates on plants. Freshwater Biology, vol. 48, p. 718-728.

TEWS, J., BROSE, U., GRIMM, V., TIELBÖRGER, K., WICHMANN, MC., SCHWAGER, M. and JELTSCH, F. 2004. Animal species diversity driven by habitat heterogeneity/diversity: the importance of keystone structures. Journal of Biogeography, vol. 31, p. 79-92.

THEEL, HJ., DIBBLE, ED. and MADSEN, JD. 2008. Differential influence of a monotypic and diverse native aquatic plant bed on a macroinvertebrate assemblage; an experimental implication of exotic plant induced habitat. Hydrobiologia, vol. 600, p. 77-87.

THOMAZ, SM., BINI, LM. and PAGIORO, TA. 2003. Macrófitas aquáticas em Itaipu: ecologia e perspectivas para o manejo. In THOMAZ, SM. and BINI, LM., ed. Ecologia e Manejo de Macrófitas Aquáticas. Maringá: Eduem. p 319-341.

THOMAZ, SM., CARVALHO, P., MORMUL, RP., FERREIRA, FA., SILVEIRA, MJ. and MICHELAN, TS. 2009. Temporal trends and effects of diversity on occurrence of exotic macrophytes in a large reservoir. Acta Oecologica, vol. 35, no. 5, p. 614-620.

THOMAZ, SM., DIBBLE, ED., EVANGELISTA, LR., HIGUTI, J. and BINI, LM. 2008. Influence of aquatic macrophyte habitat complexity on invertebrate abundance and richness in tropical lagoons. Freshwater Biology, vol. 53, p. 358-367.

TROCHINE, C., MODENUTTI, B. and BALSEIRO, E. 2006. Influence of spatial heterogeneity on predation by the flatworm Mesostoma ehrenbergii (Focke) on calanoid and cyclopoid copepods. Journal of Plankton Resource, vol. 28, p. 267-274.

URBAN, RA., TITUS, JE. and ZHU, W. 2006. An invasive macrophyte alters sediment chemistry due to suppression of a native isoetid. Oecologia, vol. 148 , no. 3, p. 455-463.

VAN NES, EH., SCHEFFER, M., VAN DEN BERG, MS. and COOPS, H. 2002. Aquatic macrophytes: restore, eradicate or is there a compromise? Aquatatic Botany, vol. 72, p. 387-403.

VEREECKEN, V., BAETENS, J., VIAENE, P., MOSTAERT, F. and MEIRE, P. 2006. Ecological management of aquatic plants: effects in lowlands streams. Hydrobiologia, vol. 570, p. 205-210.

VERMEIJ, GJ. 1996. An agenda for invasion biology. Biological Conservation, vol. 78, no. 1-2, p. 3-9.

VIEIRA, LCG., BINI, LM., VELHO, LFM. and MAZĀO, GR. 2007. Influence of spatial complexity on the density and diversity of periphytic rotifers, microcrustaceans andtestate 
amoebae. Fundamental and Applied Limnology, vol. 170, p. 77-85.

VITOUSEK, PM., D’ANTONIO, CM., LOOPE, LL., REJMÁNEK, M. and WESTBROOKS, R. 1997b. Introduced species: a significant component of human-caused global change. New Zealand Journal of Ecology, vol. 21, no. 1, p. 1-16.

VITOUSEK, PM., MOONEY, H.A., LUBCHENCO, J. and MELILLO, J.M. 1997a. Human domination of earth's ecosystems. Science, vol. 277, no. 5325, p. 494-499.

VONO, V. and BARBOSA, AR. 2001. Habitats and littoral zone fish community structure of two natural lakes in southeast Brazil. Environmental Biology of Fishes, vol. 61, p. 371-379.

WARFE, DM., BARMUTA, LA. and WOTHERSPOON, S. 2008. Quantifying habitat structure: surface convolution and living space for species in complex environments. Oikos, vol. 117, p. 1764-1773.

WETZEL, RG. 2001. Limnology: Lake and river ecosystems. San Diego: Academic Press. 998 p.

WIENS, JA. 1989. Spatial scaling in ecology. Functional Ecology. vol. 3, p. 385-397.

Received: 05 April 2010 Accepted: 17 October 2010 